\title{
RESEARCH PAPER \\ Accumulation of macronutrients and productivity of potato with foliar application of biofertilizer
}

\author{
Lucas Pinheiro Araújo ${ }^{1}$, Roberta Camargos de Oliveiraํㅜ, Regina Maria \\ Quintao Lana ${ }^{1}$, Jose Magno Queiroz Luz ${ }^{1}$, João Paulo Apolinário \\ Guimarães ${ }^{1}$, and Erlani de Oliveira Alves ${ }^{2}$ \\ ${ }^{1}$ Universidade Federal de Uberlândia/UFU, Instituto de Ciências Agrárias. BR 050 km 78, Campus Glória, \\ 38410-337 Uberlândia, MG, Brasil. \\ ${ }^{2}$ Universidade do Estado de Santa Catarina-UDESC-CAV. Av. Luiz de Camões, 2090 - Conta Dinheiro - \\ Lages - SC, Brasil.
}

\begin{abstract}
L.P. Araújo, R.C. Oliveira, R.M.Q. Lana, J.M.Q. Luz, J.P.A. Guimarães, and E.O. Alves. 2020. Accumulation of macronutrients and productivity of potato with foliar application of biofertilizer. Int. J. Agric. Nat. Resour. 70-82. The addition of organic compounds to fertilizers has shown positive effects on plant metabolism. This study aimed to evaluate the macronutrient accumulation and productivity of potato with the use of biofertilizer (BF) applied to the leaves. A $2 \times 7$ factorial plot with a plot subdivided in time and ten replications used two forms of fertilization: a chemical fertilizer with conventional NPK (nitrogen, phosphorus and potassium: control) and conventional fertilizer plus biofertilizers (BF); evaluations were performed 31, 41, 51, 61, 71, 81 and 91 days after planting (DAP) using the Jelly cultivar. The $\mathrm{BF}$ increased the maximum $\mathrm{N}, \mathrm{K}, \mathrm{Ca}$ and $\mathrm{Mg}$ accumulations in the leaves, especially $\mathrm{N}$ and $\mathrm{K}$, with the period of greatest accumulation occurring between 62 and 66 DAP. The accumulations of N, P, K, Ca and Mg in the tubers accelerated from 71 DAP. At the end of the cycle (e.g., 91 DAP), the increases in the nutrient accumulations of N, P, K and Ca were between 30 and $64 \%$ higher for the $\mathrm{BF}$ application, the $\mathrm{Mg}$ accumulations doubled and the $\mathrm{S}$ accumulations exhibited no differences between the evaluation periods. For the leaves, the following decreasing sequence of maximum accumulation was observed: $\mathrm{K}>\mathrm{N}>\mathrm{Ca}>\mathrm{Mg}>\mathrm{S}>\mathrm{P}$. For the tubers, the following decreasing sequence was obtained: $\mathrm{K}>\mathrm{N}>\mathrm{P}>\mathrm{Ca}>\mathrm{Mg}>\mathrm{S}$. The use of biofertilizers caused higher productivity of tubers of greater caliber and soluble solids contents in the cv. Jelly potato tubers.
\end{abstract}

Keywords: Jelly cultivar, nutrient absorption curves, organomineral fertilizers, Solanum tuberosum.

\section{Introduction}

Potato (Solanum tuberosum L.) is considered to be of great nutritional importance since it provides

Received Jun 22, 2020. Accepted Aug 03, 2021

Corresponding author: jmagno@ufu.br carbohydrates, salts, vitamins, proteins with nonallergic properties and antioxidants with high biological value (Hussain et al., 2021). In Brazil, the average potato productivity is $30.4 \mathrm{t} \mathrm{ha}^{-1}$ (IBGE, 2020). The relatively short cycle and high yields per area cause potato crops to be very demanding with respect to nutrients, especially for nutrients 
that in readily available forms in soil solutions (Fernandes et al., 2011; Almeida et al., 2018). However, the intensive use of chemicals creates long-term adverse effects on both ecosystems and soil health, which lead to environmental problems and increased production costs (Pradhan et al., 2018; Nyawade et al., 2019).

Organic sources, which have traditionally been underutilized, are therefore of interest because they improve the physical, chemical and biological properties of the soil and improve the production quality of potato (Tian et al., 2017; Thomas et al., 2019). Hattab et al. (2019) observed higher nutrient concentrations for vegetables grown on organic farms than those grown on conventional farms.

A combination of organic elements with minerals can reduce inorganic fertilization and can also provide positive influences for environmental protection and waste management without compromising the production of foods in terms of both quantity and quality, as observed by Czekała et al. (2019). Thus, the search for efficient fertilizer alternatives has led to the development of a class of products that are enriched with organic matter, namely, biofertilizer (BF). Crops that are treated by $\mathrm{BF}$ have the highest or similar values of leaf areas and yields (Kominko \& Gorazda, 2017). BF use has become widespread in Brazil and has the potential for its use to expand other localities, since organic sources are abundant, especially in regions near factories (Magela et al., 2019).

When using methods such as fertigation or foliar fertilization, BF products in liquid form can be used. However, because the practice is still recent in horticulture, how these products act and influence plant growth, productivity, vegetable quality and the absorption dynamics (Souza et al., 2017) is not clear. Therefore, the objective of this study was to determine the nutrient accumulations and productivity of potato, cv. Jelly, under the use of liquid biofertilizers (BF), that were applied to the leaves.

\section{Materials and Methods}

The experiment was conducted between March and July 2012 in the municipality of Perdizes $\left(19^{\circ} 21^{\prime} 10^{\prime \prime} \mathrm{S}\right.$ and $\left.47^{\circ} 17^{\prime} 34^{\prime \prime} \mathrm{W}\right)$ in the state of Minas Gerais. The climate of the region has two well-defined seasons, with cold and dry winters with annual average temperatures of $20.4{ }^{\circ} \mathrm{C}$ ( $\mathrm{Aw}$, according to the KÖPPEN classification). During the experiment, a total precipitation of $119.8 \mathrm{~mm}$ was recorded.

A $2 \times 6$ factorial plot in a banded design, with plots subdivided in time and with ten replications, used two forms of fertilization: a chemical fertilizer with conventional NPK (control) and a conventional fertilizer plus biofertilizers (BF) and totaled 20 plots. Each plot consisted of six lines, with spacings of $0.8 \mathrm{~m}$ and lengths of 10 meters, which had a total area of $48 \mathrm{~m}^{2}$.

Soil preparation was performed based on the recommendations for potato cultivation that involved plowing followed by trenching/levelling and subsequent opening of the grooves. Fertilization was performed mechanically and was placed in the planting grooves, where potatoes from type I seeds (e.g., tubers with diameters of 50 to 60 $\mathrm{mm}$ ) were planted. The nutrient amounts (e.g., $\mathrm{N}$, $\mathrm{P}$ and $\mathrm{K}$ ) that were applied to the soil were based on a soil analysis and on the recommendations of the Soil Fertility Commission of Minas Gerais. The physical and chemical analysis of the $0-20$ cm layer showed the following: $\mathrm{pH} \mathrm{H}_{2} \mathrm{O}=5.8, \mathrm{P}$ $=14.6 \mathrm{mg} \mathrm{dm}^{-3}, \mathrm{~K}=54.5 \mathrm{mg} \mathrm{dm}^{-3}, \mathrm{Ca}=4 \mathrm{cmol}_{\mathrm{c}}$ $\mathrm{dm}^{-3}, \mathrm{Mg}=1.1 \mathrm{cmol}_{\mathrm{c}} \mathrm{dm}^{-3}, \mathrm{Al}=0.0 \mathrm{cmol}_{\mathrm{c}} \mathrm{dm}^{-3}$, M.O. $=1.9 \%$, and $\mathrm{SB}=5.24$.

The control treatment consisted of an application of $1000 \mathrm{~kg} \mathrm{ha}^{-1}$ of agricultural gypsum, $1950 \mathrm{~kg}$ $\mathrm{ha}^{-1}$ of the formulated $02-30-04$ fertilizer in the plantation, $260 \mathrm{~kg} \mathrm{ha}^{-1}$ of $00-00-60$ fertilizer in the first coverage at $24 \mathrm{DAP}$ and $125 \mathrm{~kg} \mathrm{ha}^{-1}$ of 33-00-01 fertilizer in the second coverage at 31 DAP. The N, $\mathrm{P}$ and $\mathrm{K}$ sources used were as follows: the phosphorus source $\left(\mathrm{P}_{2} \mathrm{O}_{5}\right)$ was in the 
form of single superphosphate, with $17 \% \mathrm{P}_{2} \mathrm{O}_{5}$; (N) was in the form of urea, with $43 \% \mathrm{~N}$ and the potassium source $(\mathrm{K})$ was in the form of potassium chloride, with $57 \% \mathrm{~K}_{2} \mathrm{O}$.

The BF treatment complemented the control treatment with commercial biofertilizer products at different levels at different times of the plant cycle (Table 1). The BF was applied at the time of planting and at $31,41,51,61,71$ and 81 days after planting at levels of $3.7 \mathrm{~L} \mathrm{ha}^{-1}$ and 4, 4, 2, 4, 4 and $3 \mathrm{~L} \mathrm{ha}^{-1}$, respectively.

For the biofertilizer applications, a self-propelled sprayer, Case Patriot 350, which used a fan-type jet, Jet Model XR 11004, was used. After 31 days, two plants (leaves, stems and tubers) per plot were collected every ten days, which totaled six collections by the end of the experiment.

The plants were conditioned in plastic bags and sent to the laboratory for analysis. The fresh masses of the shoots (leaves and stems) and fresh masses of the tubers were weighed by using an electronic weighing device. At this stage, the materials were subjected to a washing process, and after removing the excess water, the samples were placed in paper bags and dried in an oven with forced air circulation $\left(65^{\circ} \mathrm{C} \pm 5^{\circ} \mathrm{C}\right)$ for 96 hours. The tubers were cross-sectioned to facilitate drying. After drying, the samples were weighed again, and the dry masses present in the samples were obtained. Part of the material was sent to the soil analysis laboratory, where the contents and quantities of the macronutrients were determined, which included the nitrogen $(\mathrm{N})$, phosphorus $(\mathrm{P})$, potassium $(\mathrm{K})$, calcium $(\mathrm{Ca})$, magnesium $(\mathrm{Mg})$ and sulfur $(\mathrm{S})$ that were contained in the leaf and tuber samples.

The samples were disintegrated in a plant mill with mesh number 20, and the ground material was submitted for nutrient content analyses according to the methodology described by EMBRAPA (1999). The accumulations were obtained by multiplying the dry mass by the content, which resulted in the mass in grams per plant.

At 105 DAP, manual harvesting of the tubers of all plants that were contained in the 2 central lines was performed, and those plants that were within one meter of each end of the plots were omitted. The harvested tubers were classified, and the yields per useful area of the plot $\left(12.8 \mathrm{~m}^{2}\right)$ were

Table 1. Dosages and days of application of the liquid biofertilizers that were applied in the cultivation of the potato cultivar, Jelly.

\begin{tabular}{|c|c|c|c|c|c|c|c|c|c|c|c|c|}
\hline & Level & $\mathrm{TOM}^{1}$ & $\mathrm{TOC}^{2}$ & $\mathrm{~N}^{3}$ & $\mathrm{~K}^{3}$ & $\mathrm{Ca}^{3}$ & $\mathrm{~B}^{3}$ & $\mathrm{~S}^{3}$ & $\mathrm{Mg}^{3}$ & $\mathrm{Mn}^{3}$ & $\mathrm{Zn}^{3}$ & $\mathrm{Cu}^{3}$ \\
\hline & $\mathrm{L} \mathrm{ha}^{-1}$ & & & & & & $\mathrm{~g} \mathrm{~L}^{-1}$ & & & & & \\
\hline Planting & 3.7 & 540.5 & 310.5 & 241.5 & 23 & - & - & - & - & - & - & - \\
\hline 31 and 41 & 4 & 356.5 & 207 & 115 & 11.5 & 104 & 30.5 & 78 & 6.5 & 17.2 & 5.7 & 6.5 \\
\hline 51 & 2 & 356.5 & 207 & 115 & 11.5 & 104 & 24 & - & - & 17.2 & 5.7 & - \\
\hline 61 & 4 & - & - & 45 & 450 & 104 & 24 & 62 & 49.6 & - & - & - \\
\hline 71 & 4 & 356.5 & 207 & 160 & 461.5 & 104 & 24 & - & - & 17.2 & 5.7 & - \\
\hline 81 & 3 & - & - & 45 & 450 & - & - & 62 & 49.6 & - & - & - \\
\hline
\end{tabular}

${ }^{1}$ Total organic matter; ${ }^{2}$ Total organic carbon; ${ }^{3}$ Soluble in water. 
obtained by electronic weighing. Subsequently, the following mathematical model was used to estimate the productivity per hectare $\left(\mathrm{kg} \mathrm{ha}^{-1}\right)$ : $10.000 \mathrm{~m}^{2} *$ quantity of tubers harvested in the useful area $(\mathrm{kg}) / \mathrm{useful}$ area $\left(\mathrm{m}^{2}\right)$.

The classification of the tubers used two sieves with mesh sizes of 45 and $36 \mathrm{~mm}$. Four parameters were established for the tubers: $1=$ upper (diameter $>45 \mathrm{~mm}), 2=$ medium $(45 \leq$ diameter $<36 \mathrm{~mm}$ ), $3=$ lollipop $(\geq 36 \mathrm{~mm})$ and $5=$ discard (damaged by impacts or diseases).

The analyses of the soluble solids contents were conducted using the densimeter technique, which consisted of removing 3.63-kg samples of tubers from each plot. These samples were immersed in a tank with a capacity of 100 liters of water, in which the tubers were submerged. From the estimates, the specific mass of each sample relative to the content of soluble solids was expressed as a percentage. Due to the normality, homogeneity and additivity assumptions for the parametric tests, some of the variables used throughout this work were subjected to a data transformation to the root of $x$ by using SPSS Statistics software.

The data were submitted for analyses of variance by the $5 \%$ significance test with the aid of the Sisvar program. Tukey's test at 5\% was used to detect the differences between the two treatments (e.g., control and biofertilizer), while polynomial regressions were used for the evaluation times during the cycle (Ferreira, 2014).

\section{Results and Discussion}

\section{Nitrogen (N)}

The $\mathrm{N}$ accumulations in the leaves exhibited a better fit to the quadratic model, whose maximum points were 1.32 and 0.96 g plant $^{-1}$ at 62 and 63 days after planting (DAP), for the BF treatment and control, respectively (Fig. 1A). For the tubers, the growth amounts were linear and reached maximum values of 3.84 and $2.85 \mathrm{~g} \mathrm{plant}^{-1}$ at 91 DAP (Fig. 1B). Yorinori (2003), who used with the Atlantic cultivar in the dry season, obtained values of 0.28 and 2.73 g plant $^{-1}$ at the critical points of 52 and 90 DAP for the leaves and tubers, respectively. In addition, Fernandes et al. (2011), who used the Ágata, Asterix, Markies and Mondial cultivars, found maximum $\mathrm{N}$ accumulations that ranged from 0.68 to 1.17 g plant $^{-1}$ from 70 to 76 DAP for the leaves. In the tubers, the authors estimated values between 2.12 and 2.21 g plant $^{-1}$ at the end of the cycle.

The values obtained by Fernandes et al. (2011) were close to those found in this study, and highlight the variations that exist in the physiology of each cultivar, which result in distinct accumulation potentials. When we consider the accumulations, we also need to pay attention to the climatic conditions of the growing regions because these also determine the $\mathrm{N}$ levels in plants. The plants that received BF foliar applications showed superior accumulations in the leaves and tubers. This was due to the $\mathrm{N}$ contents of the $\mathrm{BF}$. The foliar supplies were responsible since $\mathrm{N}$ is a component of chlorophyll, which is the molecule that is responsible for photosynthesis. Thus, the $\mathrm{N}$ levels increased the potential for dry matter production, which, together with its wide redistribution in the plants, causes $\mathrm{N}$ to be the element of greatest impact on the production and quality of tubers (Koch et al., 2020).

In the study of the treatments at each collection date, the $\mathrm{N}$ accumulations in the leaves that received $\mathrm{BF}$ were higher than those of the control treatment at 51 and 61 DAP but were lower at 81 DAP (Fig. 1A). In the tubers, there were differences only for the last collection where the $\mathrm{BF}$ treatment showed $64 \%$ higher $\mathrm{N}$ levels (Fig. 1B), which demonstrated the effect of this treatment on the $\mathrm{N}$ accumulations in these organs. Mohamed et al. (2017) found that the response to green manure was greater than that of mineral fertilizers, with higher $\mathrm{N}$ accumulations in potato at higher sun hemp doses, which were related to the rapid 
mineralization and $\mathrm{N}$ release of the green manure tissues (Watthier et al., 2020).

\section{Phosphorus (P)}

The maximum phosphorus accumulation in the leaves was $0.39 \mathrm{~g} \mathrm{plant}^{-1}$ at 56 DAP (Fig. 1A). In the tubers, the accumulations were linear, as shown in Fig. 1B, with maximum values of 1.56 and $1.22 \mathrm{~g}$ plant $^{-1}$ for the BF application and control treatments, respectively. The application of $\mathrm{BF}$ increased the $\mathrm{P}$ accumulations in the tubers by $27.8 \%$ at the end of the cycle. The $\mathrm{N}$ and $\mathrm{P}$ uptakes were synergistic, which indicated interactions and balance between the nutrients. The effects of the $\mathrm{N}$ and $\mathrm{P}$ nutrients are more relevant to the production when they are together, and the presence of adequate levels of these two is fundamental for plant growth (Silva \& Trevizam, 2015).

Yorinori (2003) found the maximum P accumulations for the Atlantic cultivar with values of 0.02 and $0.39 \mathrm{~g} \mathrm{plant}^{-1}$ at 39 and 111 DAP for the leaves and tubers, respectively. The values obtained in this study were higher, which are probably due to the cultivars used. In addition, the climatic conditions and nutrient availabilities in the soil allow rational determinations to predict additional fertilizer applications to the plants, since imbalances between nutrients can be found, as well as luxury consumption, which does not cause increased productivity in short producers.

The leaves exhibited a large decrease in P contents at the end of the cycle. P was absorbed and accumulated in the first stages of development (Fernandes et al., 2011). In addition, the accumulations decrease in the leaves after the critical points due to the translocation and natural senescence of these organs, and greater accumulations in the tubers were observed in the last evaluations, which were observed in this study with greater final maximum accumulations in the tubers. The BF application generated $\mathrm{P}$ accumulations that were 27.2 and $71.4 \%$ higher than the control
(Fig. 1A) in the leaves and tubers, respectively (Fig. 1B). Yang et al. (2019) suggested that the constituents of BF, such as humic acids, enable biomass and $\mathrm{P}$ accumulation in plants.

\section{Potassium (K)}

The BF treatment reached a maximum of $2.43 \mathrm{~g}$ plant $^{-1}$ at $62 \mathrm{DAP}$ and the control treatment reached a maximum of $1.85 \mathrm{~g} \mathrm{plant}^{-1}$ at 64 DAP (Fig. 1A). The accumulations in the tubers followed a linear trend for both treatments, which reached 7.41 and 7.86 g plant $^{-1}$ at the end of the evaluations (91 DAP), respectively (Fig. 1B). Yorinori (2003) obtained values of 1.10 and 3.20 g plant $^{-1}$ at 46 and 90 DAP for the leaves and tubers, respectively. Fernandes et al. (2011) obtained maximum values in the leaves that were close to the results of this research, which were estimated to be between 1.70 and 2.68 plant ha $^{-1}$ and reached 74 to 76 DAP. K is the nutrient that is most absorbed by crops and is the most abundant cation in plants. However, the literature notes that excessive potassium use in the soil can impair the production of tubers by increasing the $\mathrm{K}^{+} /\left(\mathrm{Ca}^{2+}+\mathrm{Mg}^{2+}\right)$ ratio due to antagonism in the uptake of these nutrients (Reis Júnior \& Monnerat, 2001; Mugo et al., 2021).

In the present study, the $\mathrm{K}$ accumulations in the leaves for the BF treatment were superior at 51 and 61 DAP, which coincide with the tuberization phase. In the tubers, the control treatment was superior at 71 and 81 DAP (e.g., 39 and 53\%, respectively) but at $91 \mathrm{DAP}$, the $\mathrm{K}$ accumulations in the tubers that received the BF treatment were approximately $30 \%$. The increases from 71 to 91 DAP were $61 \%$ and $29.8 \%$ in the BF and control treatments, respectively (Fig. 1A and 1B).

\section{Calcium (Ca)}

The maximum $\mathrm{Ca}$ accumulation in the leaves was $1.01 \mathrm{~g} \mathrm{plant}^{-1}$ at $63 \mathrm{DAP}$ in the BF treatment and $0.93 \mathrm{~g} \mathrm{plant}^{-1}$ at 66 DAP in the control treat- 

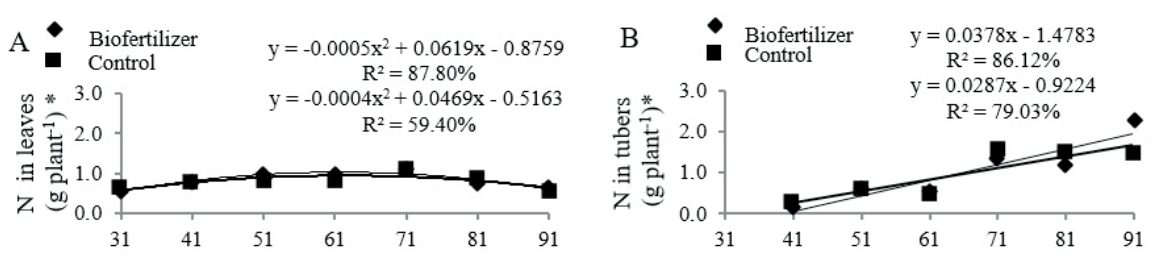

Days after planting
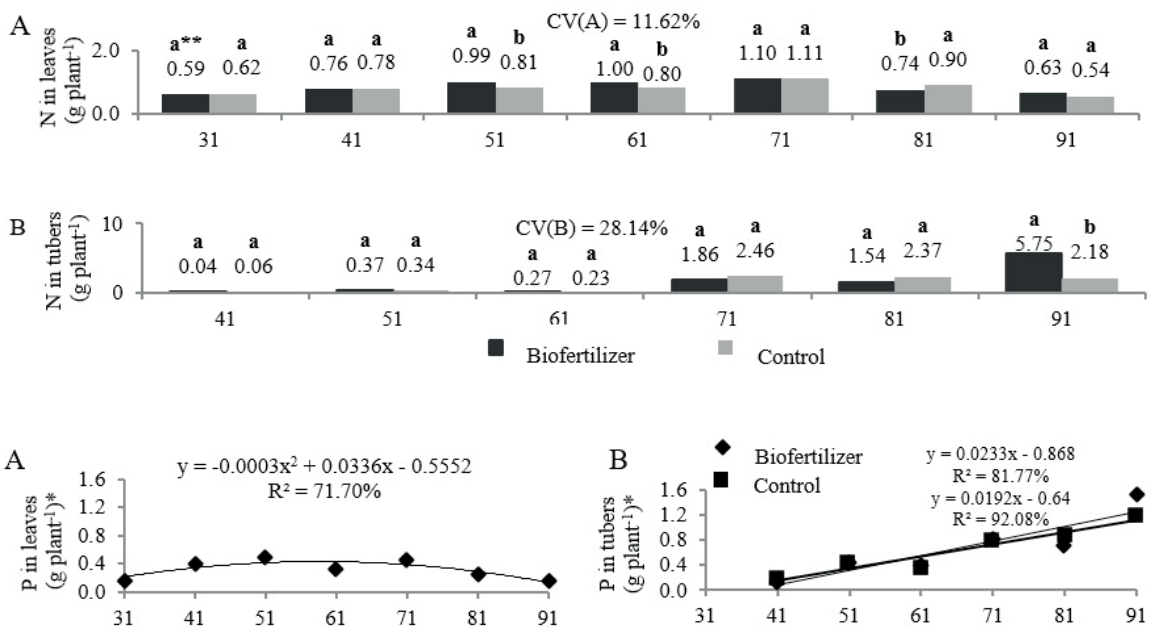

Days after planting
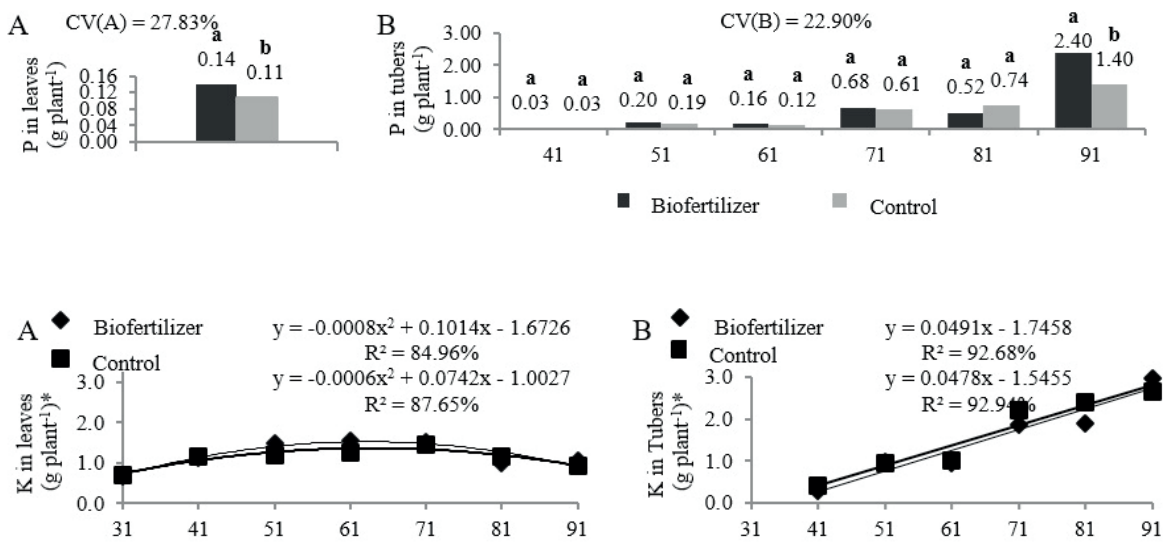

Days after planting
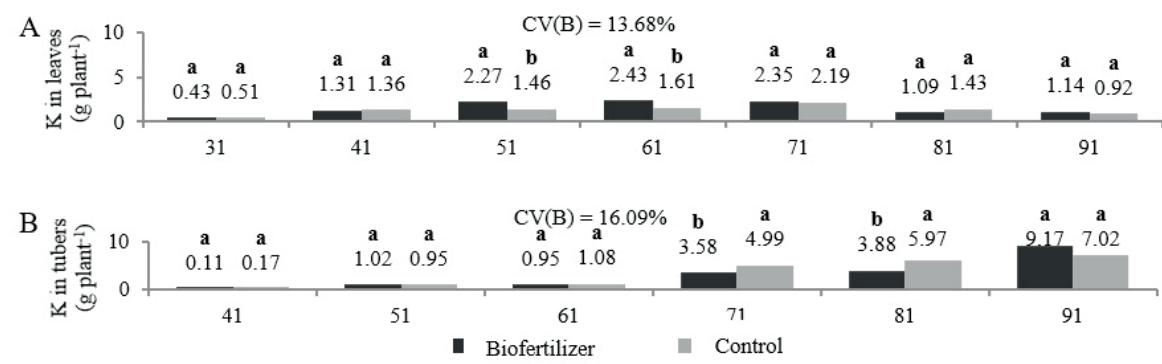

Figure 1. Nitrogen (N), phosphorus (P) and potassium (K) accumulations in leaves (A) and tubers (B) throughout the cycle and comparisons of treatments. 
ment (Fig. 2A). In the tubers, the BF treatment obtained a maximum of $1.49 \mathrm{~g} \mathrm{plant}^{-1}$ at $91 \mathrm{DAP}$, while the control that used to the linear model had a maximum Ca accumulation of 0.58 g plant $^{-1}$ at 91 DAP (Fig. 2B). The results obtained by Yorinori (2003) indicated maximum values of 0.23 and 0.4 g plant $^{-1}$ at 51 and 90 DAP for the leaves and tubers, respectively. Fernandes et al. (2011) obtained maximum values between 0.74 and $0.99 \mathrm{~g} \mathrm{plant}^{-1}$ at 85 and 90 DAP for the leaves and 0.11 and 0.19 at 97 DAP for the tubers. This study found results that were superior to those published in the literature, especially for those plots that received the $\mathrm{BF}$ treatment, by the concentration of $\mathrm{Ca}$ present in the foliar fertilizers.

For potato crops, most $\mathrm{Ca}$ is commonly supplied by liming. For Pulz et al. (2008) and Parecido et al. (2021), the application of limestone to the soil increased the productivities in the vast majority of cases. In this sense, because $\mathrm{Ca}$ is a component of the cell walls of plants, the high availability of $\mathrm{Ca}$ in the soil also results in incremental improvements in crop vegetative development. However, calcium is an immobile nutrient, with low translocation levels between plant organs (Koch et al., 2020). Thus, larger accumulations tend to be found in the leaves and to a lesser extent, in the tubers, although $\mathrm{Ca}$ is an important constituent of these organs. These proportions were observed in the plants that did not receive $\mathrm{BF}$.

For the products that were rich in $\mathrm{Ca}$, as was the case for the applications at 31, 41, 51, 71 and 81 DAP, the aim was to correct any deficiencies. It was observed in this study that there were significant differences in the $\mathrm{Ca}$ accumulations in the leaves at 51 and 61 DAP, with the BF treatment being superior to the control treatment (Fig. 2A). For the tubers, the difference between treatments was manifested at 91 DAP, which may mean that late applications of the product induce $\mathrm{Ca}$ accumulation of in the tubers, with the accumulation being 2.6 times higher under BF applications (Fig. 2B).

\section{Magnesium (Mg)}

For the $\mathrm{Mg}$ accumulations in the leaves, the maximum value of $0.26 \mathrm{~g}$ plant $^{-1}$ was obtained at 62 DAP for the BF treatment and $0.22 \mathrm{~g} \mathrm{plant}^{-1}$ at 63 DAP for the control treatment (Fig. 2A). For the tubers, the treatments followed the linear models, with the BF treatment providing a maximum value of $0.79 \mathrm{~g} \mathrm{plant}^{-1}$, while the control treatment provided a maximum value of $0.66 \mathrm{~g} \mathrm{plant}^{-1}$ at 91 DAP (Fig. 2B).

In a study carried out by Yorinori (2003), the leaves exhibited maximum accumulations of $0.06 \mathrm{~g} \mathrm{plant}^{-1}$, and the tubers exhibited maximum accumulations of $0.11 \mathrm{~g} \mathrm{plant}^{-1}$ at 46 and 90 DAP, respectively. In similar research, Fernandes et al. (2011) stated that the maximum values were between 0.09 and $0.20 \mathrm{~g} \mathrm{plant}^{-1}$ for the leaves from 73 to 78 DAP and were 0.17 to $0.22 \mathrm{~g} \mathrm{plant}^{-1}$ for the tubers at the end of the cycle.

$\mathrm{Mg}$ is absorbed in smaller amounts and is supplied mainly by liming, and its absorption may be impaired by fertilization with heavy levels of $\mathrm{K}$. When the soil is poor, foliar applications may complement the need for Mg. Thus, in the case of $\mathrm{Mg}$, significant differences were observed in the leaves at 51 and 61 DAP, and the BF treatment was superior. For this treatment, fertilizers rich in Mg were used at 31, 41 and 61 DAP. This is consistent with the values that are presented by the accumulation charts at different times. For the tubers, the BF treatment was significantly lower at 81 DAP but doubled at 91 DAP when compared to the control (Fig. 2).

\section{Sulfur (S)}

For the sulfur accumulations, there were no significant interactions for the leaves or tubers (Fig. 2). For the leaves, a quadratic curve was used with a maximum value of $0.24 \mathrm{~g} \mathrm{plant}^{-1}$ at 63 DAP. The accumulations in the tubers followed a quadratic equation, and a minimum 

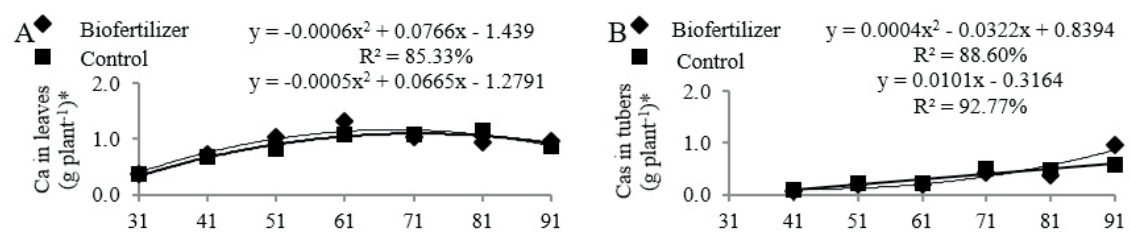

Days after planting
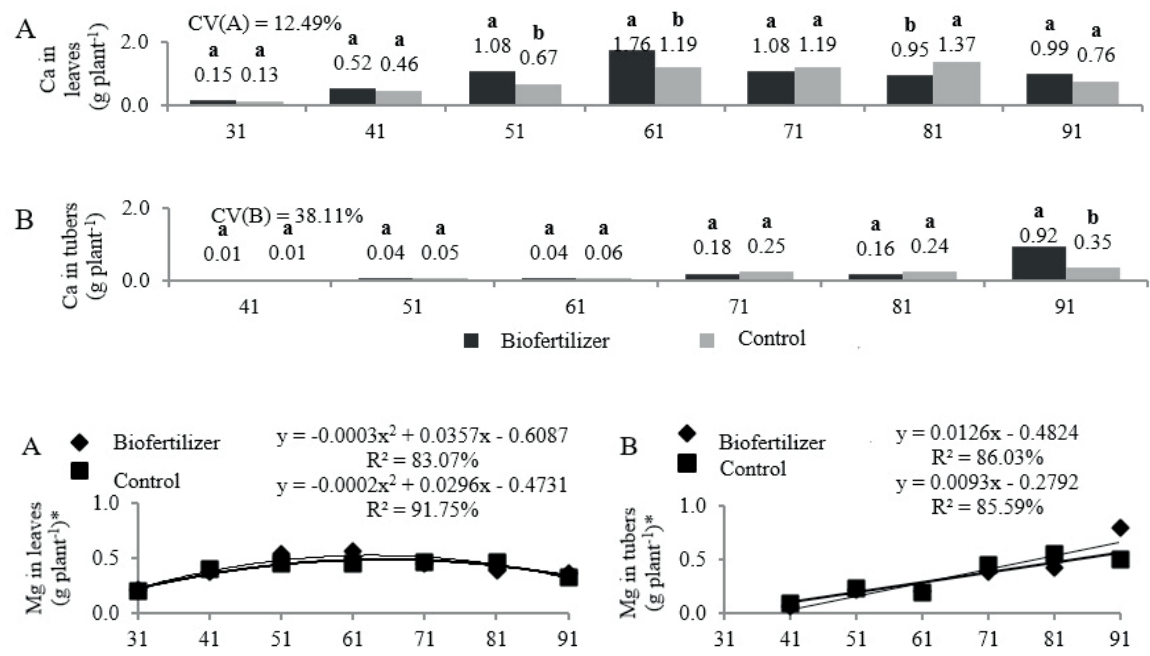

Days after planting
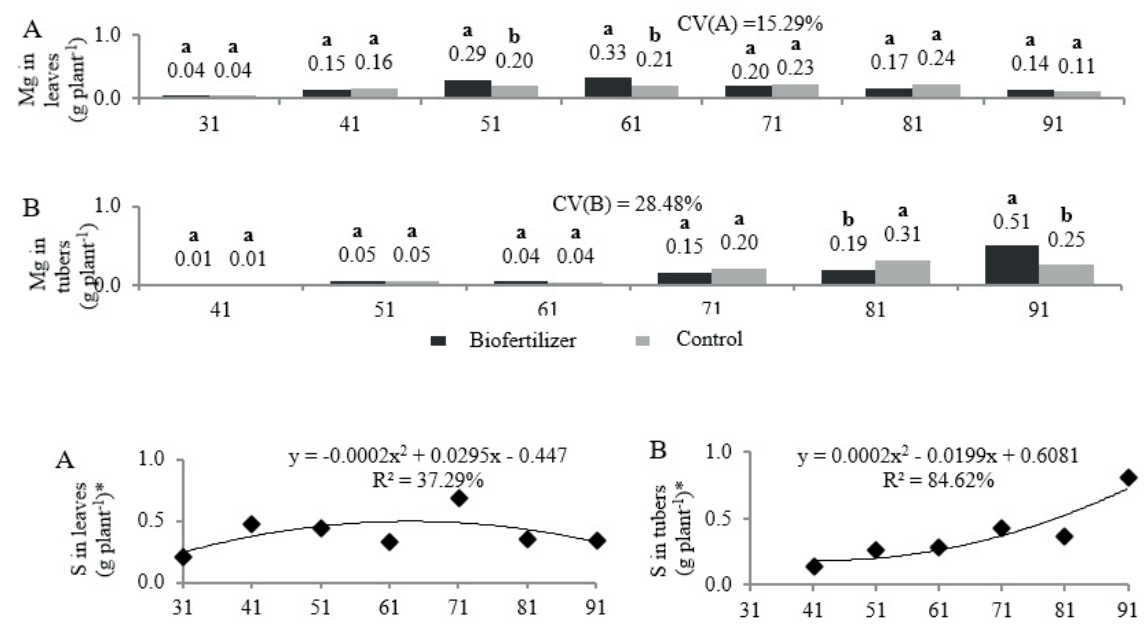

Days after planting
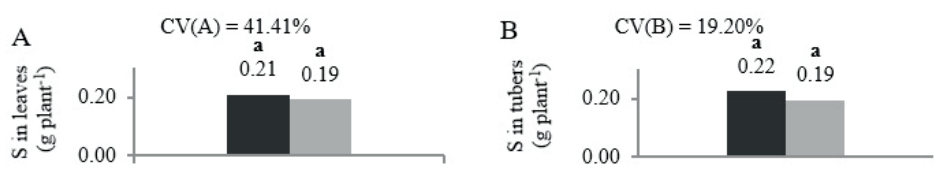

- Biofertilizer $=$ Control

Figure 2. Calcium (Ca), magnesium ( $\mathrm{Mg}$ ) and sulfur $(\mathrm{S})$ accumulations in leaves $(\mathrm{A})$ and tubers (B) throughout the cycle and comparisons of treatments. 
value of $0.42 \mathrm{~g} \mathrm{plant}^{-1}$ was observed at 41 DAP. Fernandes et al. (2011), who studied five potato cultivars, stated that there were maximum $\mathrm{S}$ accumulations between 0.04 and 0.07 g plant $^{-1}$ from 77 to 83 DAP. In this work, the results were higher, possibly due to the contribution of BF. For the leaves and tubers, there were no significant differences when the studied forms of fertilization were used. The accumulations were very close, with no specific organ standing out (Fig. 2A and 2B).

The $\mathrm{S}$ concentrations in the $\mathrm{BF}$ treatment did not change the dynamics of $\mathrm{S}$ in the Jelly potato cultivar. Braun et al. (2011) also did not observe any effects on the $\mathrm{S}$ contents in the tubers despite the application of increasing levels of S (from ammonium sulfate). The BF treatment increased the maximum accumulations of $\mathrm{N}, \mathrm{K}, \mathrm{Ca}$ and $\mathrm{Mg}$ in the leaves, which were between 8 and $37 \%$, especially for $\mathrm{N}$ and $\mathrm{K}$, with the period of greatest accumulation occurring between 62 and 66 DAP. In addition to providing nutrients by increasing plant concentrations, the compounds present in BF can induce changes in the primary and secondary metabolisms of the plants that are related to the tolerance to abiotic and biotic stress. BF use also increases sustainability due to the cycling of organic residues from many sources (low production costs) and can improve plant resilience to various biotic and abiotic stresses (Malik et al., 2021). Therefore, BF can be used to provide a mechanism to improve and rationalize crop management, which makes it possible to produce tubers with better nutritional balance.

\section{Productivity and soluble solids contents}

At 105 DAP, the plants that received BF applications provided total tuber yields of $40.87 \mathrm{tha}^{-1}$ and had diameters greater than $45 \mathrm{~mm}-35 \mathrm{t} \mathrm{ha}^{-1}$ (Fig. $3 \mathrm{~A}$ ), which demonstrated that BF influenced the plant metabolisms. This possibility can be related to the $\mathrm{N}$ and other compounds present in the $\mathrm{BF}$, which influence the formation and absorption of essential molecules that are important for plant development (Taiz et al., 2017) and have the potential to maintain the strong development of the aerial parts and growth of tubers. The use of $\mathrm{BF}$ promoted increases in the production of larger diameter tubes, which increased the value and quality of the final product. Studies have reported increases in productivity and improvements in the quality of tubers from the use of BF applications when compared to the application of only chemical fertilizers for the Atlantic and Agata cultivars (Cardoso et al., 2015; Cardoso et al., 2017). Mohamed et al. (2017) found that the productivity of potatoes was $24 \%$ greater with green manure than with mineral fertilization, which indicated the potential of alternative fertilizers to provide nitrogen for the growth and development of potato.

The soluble solids contents (SS) were significant with the BF treatment. It is possible that BF released sulfate ions, which facilitated the formation of soluble solids in the tubers and roots and allowed mass accumulations in the tubers of the Jelly cultivar (Fig. 3C). It is important to highlight that the specialized horticultural production using BF permits the reuse of large quantities of alternative sources of organic mass from waste that is produced in various industrial processes (Chew et al., 2019; Soobhany, 2019; FernándezDelgado et al., 2020).

\section{Conclusions}

The BF treatment increased the maximum accumulations of $\mathrm{N}, \mathrm{K}, \mathrm{Ca}$ and $\mathrm{Mg}$ in the leaves, especially for $\mathrm{N}$ and $\mathrm{K}$, with the period of greatest accumulation occurring between 62 and 66 DAP. The accumulations of N, P, K, Ca and $\mathrm{Mg}$ in the tubers accelerated from 71 DAP. At the end of the cycle (91 DAP), the increases in nutrient accumulations of N, P, K and Ca were between 30 and $64 \%$ higher for the $\mathrm{BF}$ application, the $\mathrm{Mg}$ accumulations doubled, and 

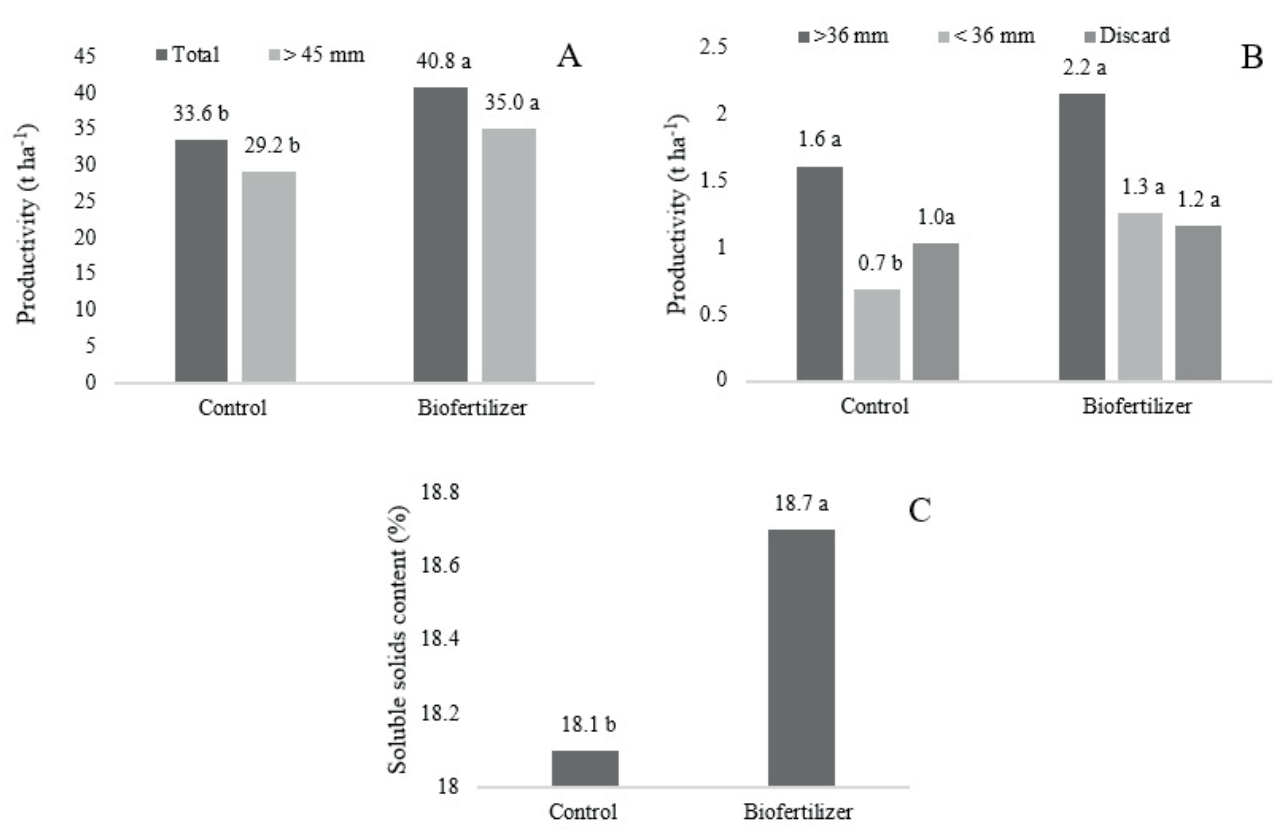

Figure 3. Total productivity (t ha-1) and productivity of larger diameter tubers $(>45 \mathrm{~mm})(\mathrm{A})$, productivity of tubers larger than $36 \mathrm{~mm}$, smaller than $36 \mathrm{~mm}$ and discarded (B) and soluble solids contents (\%) (C) from different fertilizations.

the $\mathrm{S}$ accumulations did not differ between the evaluation periods.

For the leaves, the following decreasing sequence of maximum accumulation levels was obtained: $\mathrm{K}>\mathrm{N}>\mathrm{Ca}>\mathrm{Mg}>\mathrm{S}>\mathrm{P}$. For the tubers, the following sequence was obtained: $\mathrm{K}>\mathrm{N}>\mathrm{P}>\mathrm{Ca}>\mathrm{Mg}>\mathrm{S}$. Foliar applications of $\mathrm{BF}$ can be an important tool for nutritional management since the absorption is efficient and can be applied in the period of greatest need of the plants. The use of biofertilizers shows higher tuber productivity with tubers that are of greater caliber and of the soluble solids contents in cv. Jelly potato tubers.

\section{Acknowledgment}

The authors wish to thank the Conselho Nacional de Desenvolvimento Científico e Tecnológico (CNPq), Fundação de Amparo à Pesquisa do Estado de Minas Gerais (FAPEMIG) for the financial support and Coordenação de Aperfeiçoamento de Pessoal de Nível Superior (CAPES).

\section{Disclosure statement}

No potential conflicts of interest were reported by the authors. 


\title{
Resumen
}

\begin{abstract}
L.P. Araújo, R.C. Oliveira, R.M.Q. Lana, J.M.Q. Luz, J.P.A. Guimarães, y E.O. Alves. 2020. Acumulación de macronutrientes y productividad de papa con aplicación foliar de biofertilizante. Int. J. Agric. Nat. Resour. 70-82. La adición de compuestos orgánicos en fertilizantes ha mostrado un efecto positivo en el metabolismo de las plantas. El objetivo fue evaluar la acumulación de macronutrientes en tubérculos de papa con el uso de biofertilizantes líquidos (BF), aplicados a través de la hoja. El diseño experimental fue factorial $2 \times 7$ con una división en el tiempo y diez repeticiones, consistió en dos formas de fertilización: química con NPK convencional (control) y convencionales más biofertilizantes (BF) y evaluaciones en 31; $41 ; 51 ; 61 ; 71 ; 81$ y 91 días después de la siembra (DAS), utilizando el cultivar Jelly. BF favorece las acumulaciones máximas de N, K, Ca y Mg en las hojas, entre 8 y $37 \%$, especialmente para $\mathrm{N}$ y K, con un período de mayor acumulación entre 62 y 66 DAP. La acumulación de N, P, K, Ca y $\mathrm{Mg}$ en los tubérculos se acelera desde $71 \mathrm{DAP}$. Al final del ciclo (91 DAP), el aumento en la acumulación de nutrientes N, P, K y Ca es entre 30 y 64\% mayor en la aplicación de BF líquido, el Mg se acumula el doble y S no difiere entre los períodos de evaluación. Para las hojas, se obtuvo la siguiente secuencia decreciente de acumulación máxima: $\mathrm{K}>\mathrm{N}>\mathrm{Ca}>\mathrm{Mg}>\mathrm{S}>\mathrm{P}$. Para los tubérculos, se obtuvo $\mathrm{K}>\mathrm{N}>\mathrm{P}>\mathrm{Ca}>\mathrm{Mg}>\mathrm{S}$. El sou de biofertilizantes proporciona una mayor productividad de tubérculos de mayor calibre y contenido de sólidos solubles en el papa cv. Jelly.
\end{abstract}

Palabras clave: Cultivar Jelly, curvas de absorción de nutrientes, fertilizantes organominerales, Solanum tuberosum.

\section{References}

Almeida, L.S., Pereira, H.S., Cardoso, A.F., Lana, R.M.Q., Mageste, J.G., Lima, L.C., \& Luz, J.M.Q. (2018). Accumulation and export of micronutrients in potato Fertilized with organic-mineral fertilizer. Bioscience Journal, 34(1):71-80. doi: 10.14393/BJv34n6a2018-39917

Braun, H., Fontes, P.C.R., Busato, C., \& Cecon, P.R. (2011). Teor e exportação de macro e micronutrientes de cultivares de batata em função do nitrogênio. Bragantia, 70:50-57. doi: 10.1590/ S0006-87052011000100009

Cardoso, A.F., Luz, J.M.Q., \& Lana, R.M.Q. (2015). Produtividade e qualidade de tubérculos de batata em função do fertilizante organomineral e safras de plantio. Revista Caatinga, 28(4):80-89. doi: 10.1590/1983-21252015v28n409rc

Cardoso, A.F., Lana, R.M.Q., Soares, W., Peixoto, J.V.M., \& Luz, J.M.Q. (2017). Performance of organomineral fertilizer in winter and rainy po- tato crop. Bioscience Journal, 33(4):861-869. doi: 10.14393/BJ-v33n4a2017-36709

Chew, K.W., Chia, S.R., Yen, H.-W., Nomanbhay, S., Ho, Y.-C., Show, P.L. (2019). Transformation of Biomass Waste into Sustainable Organic Fertilizers. Sustainability, 11(8):1-19. doi: 10.3390/ su11082266

Czekała, W., Jeżowska, A., Chełkowski, D. (2019). The use of biochar for the production of organic fertilizers. Journal of Ecological Engineering, 20(1):1-8. doi: 10.12911/22998993/93869

EMBRAPA. Empresa Brasileira De Pecuária E Abastecimento. (1999). Centro Nacional de Pesquisa de Solos (Rio de Janeiro, RJ). Manual de análise química dos solos, plantas e fertilizantes. Embrapa Solos, $370 \mathrm{p}$.

Fernandes, A.M., Soratto, R.P., \& Silva, B.L. (2011). Extração e exportação de nutrientes em cultivares de batata: I - Macronutrientes. Revista Brasileira de Ciência do Solo, 35:2039-2056.

Fernández-Delgado, M., Amo-Mateos, E., Lucas, S., García-Cubero, M.T., Coca, M. (2020). Re- 
covery of organic carbon from municipal mixed waste compost for the production of fertilizers. Journal of Cleaner Production, 121805, 1-9. doi: 10.1016/j.jclepro.2020.121805

Ferreira, D.F. (2014). Sisvar: a Guide for its Bootstrap procedures in multiple comparisons. Ciência e Agrotecnologia, 38(2):109-112. doi: 10.1590/S1413-70542014000200001

Hattab, S., Bougattass, I., Hassine, R., Dridi-AlMohandes, B. (2019). Metals and micronutrients in some edible crops and their cultivation soils in eastern-central region of Tunisia: A comparison between organic and conventional farming. Food Chemistry, 270:193-298. doi: 10.1016/j. foodchem.2018.07.029

Hussain, M., Qayum, A., Xiuxiu, Z., Liu, L., Hussain, K., Yue, P., Yue, S., Koko, M.Y.F., Hussain, A., Li, X. (2021). Potato protein: An emerging source of high quality and allergy free protein, and its possible future based products. Food Research International, 148, 110583. doi: 10.1016/j.foodres.2021.110583

IBGE- Levantamento sistemático da produção agrícola. (2020). Retrieved from: https://www.ibge. gov.br/estatisticas/economicas/agricultura-epecuaria/9201-levantamento-sistematico-daproducao-agricola.html? $=\& \mathrm{t}=$ downloads

Koch, M., Naumann, M., Pawelzik, E., Gransee, A., Thiel, H. (2020). The importance of nutrient management for potato production part I: plant nutrition and yield. Potato Research, 63:97-119. doi: 10.1007/s11540-019-09431-2

Kominko, H., \& Gorazda, K. (2017). The possibility of organo-mineral fertilizer production from sewage sludge. Waste and Biomass Valorization, 8 (5):1781-1791. doi: 10.1007/s12649-0169805-9

Magela, M.L.M., Camargo, R., Lana, R.M.Q., Miranda, M.C.C., \& Mota, R.P. (2019). Efficacy of organomineral fertilizers derived from biosolid or filter cake on early maize development. Australian Journal of Crop Science, 13 (5):662-670. doi: 10.21475/ajcs.19.13.05.p1132

Malik, A., Mor, V.S., Tokas, J., Punia, H., Malik, S., Malik, K., Sangwan, S., Tomar, S., Singh, P., Singh, N., Himangini, Vikram, N., Singh, G.,
Vikram, Kumar, V., Sandhya, \& Karwasra, A. (2021). Biostimulant-Treated Seedlings under Sustainable Agriculture: A Global Perspective Facing Climate Change. Agronomy, 11(14):124. doi: 10.3390/agronomy 11010014

Mohamed, E.M.E., Watthier, M., Zanuncio, J.C., \& Santos, R.H.S. (2017). Dry matter accumulation and potato productivity with green manure. Idesia, 35(1):79-86. doi: 10.4067/S071834292017005000016

Mugo, N.J., Karanja, N.N., Gachene, C.K., Dittert, K., Gitari, H.I., \& Schulte-Geldermann, E. (2021). Response of potato crop to selected nutrients in Central and Eastern highlands of Kenya. Cogent Food \& Agriculture, 7:1898762. doi: 10.1080/23311932.2021.1898762

Nyawade, S. O., Gachene, C. K. K., Karanja, N. N., Gitari, H. I., Schulte-Geldermann, E., \& Parker, M. (2019). Controlling soil erosion in smallholder potato farming systems using legume intercrops. Geoderma Regional, 17:e0225. doi:10.1016/j.geodrs.2019.e00225

Parecido, R.J., Soratto, R.P., Perdoná, M.J., Guidorizzi, F.V.C., Gitari, H.I., Gomes, G.G., \& Paula, R.A. (2021). Limestone increased coffee yield and profitability more than phosphogypsum or their combination. Agronomy Journal, 1-14. doi: 10.1002/agj2.20712

Pradhan, S.S., Verma, S., Kumari, S., \& Singh, Y. (2018). Bio-efficacy of cow urine on crop production: A review. International Journal of Chemical Studies, 6(3):298-301.

Pulz, A.L., Crusciol, C.A.C., Lemos, L.B., \& Soratto, R.P. (2008). Influência de silicato e calcário na nutrição, produtividade e qualidade da batata sob deficiência hídrica. Revista Brasileira de Ciência do Solo, 32:1661-1669. doi: 10.1590/ S0100-06832008000400030

Reis Júnior, R.A., \& Monnerat, P.H. (2001). Exportação de nutrientes nos tubérculos de batata em função de doses de sulfato de potássio. Horticultura Brasileira, 19(3):227-231.

Silva, M.L.S., \& Trevizam, A.R. (2015). Interações iônicas e seus efeitos na nutrição das plantas. Informações agronômicas, 149:10-16.

Soobhany, N. (2019). Insight into the recovery of nu- 
trients from organic solid waste through biochemical conversion processes for fertilizer production: A review. Journal of Cleaner Production, 241:1-16. doi: 10.1016/j.jclepro.2019.118413

Souza, B.U., Oliveira, R.C., Luz, J.M.Q., Machado, D.L.M., \& Aguilar, A.S. (2017). Eficiência agronômica de fertilizantes organominerais líquidos em batateira, cultivar Asterix. Revista Brasileira de Ciências Agrárias, 12(4), 405-409. doi: 10.5039/agraria.v12i4a5466

Taiz, L., Zeiger, E., Moller, I., \& Murphy, A. (2017). Fisiologia e desenvolvimento vegetal. 6.ed. Porto Alegre: Artmed, 888 p.

Thomas, C.L., Acquah, G.E., Whitmore, A.P., McGrath, S.P., Haefele, S.M. (2019). The effect of different organic fertilizers on yield and soil and crop nutrient concentrations. Agronomy, 9:776, 1-15. doi: 10.3390/agronomy9120776

Tian, J., Lou, Y., Gao, Y., Fang, H., Liu, S., Xu, M., Blagodatskaya, E., Kuzyakov, Y. (2017). Response of soil organic matter fractions and composition of microbial community to longterm organic and mineral fertilization. Biology and Fertility of Soils, 53:523-532. doi: 10.1007/ s00374-017-1189-x

Yang, F., Zhang, S., Song, J., Du, Q., Li, G., Tarakina, N.V., Antonietti, M. (2019). Synthetic humic acids solubilize otherwise insoluble phosphates to improve soil fertility. Angewandte Chemie, 131:18989-18992. doi: 10.1002/ ange. 201911060

Yorinori, G.T. (2003). Curva de crescimento e acúmulo de nutrientes pela cultura da batata cv. 'Atlantic'. Piracicaba: Escola Superior de Agricultura "Luiz de Queiroz". 66 p. Dissertação Mestrado.

Watthier, M., Antonio, N.P., Gomes, J.A., Rocha, S.B.F., Santos, R.H.S. (2020). Decomposition of green manure with different grass: legume ratios. Archives of Agronomy and Soil Science, 66(7):913-924. doi: 10.1080/03650340.2019.1644622

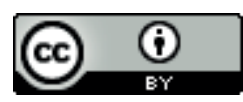

This work is licensed under a Creative Commons Attribution 4.0 International License. 